\section{STD/AIDS prevention in Portuguese-speaking Africa: a review of the recent literature in the social sciences and health}

\author{
Prevenção das DST/AIDS nos países africanos \\ de língua oficial portuguesa: revisão da literatura \\ recente em ciências sociais e da saúde
}

Simone Monteiro 1

This exploratory study reviews the literature in the field of the social sciences and health on the problems and challenges of STD/AIDS prevention in sub-Saharan Africa, with a focus on research in Portuguese-speaking African countries (known by the acronym PALOP, for Países Africanos de Língua Oficial Portuguesa): Mozambique, Angola, Cape Verde, Guinea-Bissau, Equatorial Guinea, and São Tomé and Príncipe.

The survey encompassed scientific production from 1997 to 2007 available in the SciELO, PubMed, and Sociological Abstracts databases. Methodologically, the search cross-referenced descriptors related to AIDS, African countries and prevention, and socio-cultural dimensions like gender and sexuality, among others.

The studies were divided into two groups. The first examined vulnerability to STD/AIDS among social groups, based on analyses of the cultural and socio-economic factors linked to gender roles, sexuality, emotional and sexual interactions, religious affiliation, social networks, educational level, and access to social goods and healthcare services. The second group offered critical evaluations of shortcomings in the educational STD/AIDS messages of governments and international agencies. Attention is called to the specific features of African countries, including a marked reliance on traditional medicine and recent civil wars. Although the factors examined in both groups constitute specific dimensions, in the complexity of the real world they are all inter- 
twined, with relations of mutual determination and association, and they should be interpreted in conjunction.

\section{Cultural and socio-economic dimensions of the HIV/AIDS epidemic}

The concept of gender - that is, cultural attributes associated with the female or male sex-has made its growing influence felt in the world literature on the HIV/AIDS epidemic. Interpretations of rising HIV transmission through heterosexual relations and among women, especially in contexts of socio-economic inequality and social marginality, have taken into account the implications of hierarchical relations, which are characterized by the hegemony of male power and concomitant greater female subjugation, partly grounded in the control of sexuality. These features are found in various contexts in sub-Saharan Africa. Reflecting this tendency, the literature under review explores how local gender dynamics matter to our understanding of STD/AIDS vulnerability and how these dynamics are interdependent on the socio-economic conditions of the contexts in question. The present text discusses these factors based on the surveyed studies on Portuguesespeaking African countries, except for Equatorial Guinea and São Tomé and Príncipe, where no research was identified.

Studies conducted in Mozambique, and in rural regions in particular, draw a connection between vulnerability both to the AIDS epidemic and social practices by which men control female sexuality and to childbearing and reproduction of the family, which constitutes an important cultural value. These factors clash with prevention messages centered on the negotiated use of condoms. Within this universe, widows are especially vulnerable, as they have no ownership rights to their husband's estate and are subject to rape and sexual exploitation by male family members 1 . Approaching from the factors of gender, socioeconomic conditions, educational level, and religious affiliation, other analyses have contributed to a deeper understanding of local logic systems and their implications when it comes to constructing ideas about health and risk.

In this regard, one set of research $2,3,4,5$ addresses the way in which religious beliefs in subSaharan Africa shape social and gender norms and influence the interpretation of prevention messages. One illustration of this approach is a study 2 conducted in rural Mozambique and in urban areas of the capital among members of two types of denominations: "mainline" (Catholic and Presbyterian) and "curative" (Assembly of God, Zionist, and Apostolic). The study found gender asymmetry in messages about STD/AIDS prevention and in members' views and practices within both types of denominations. Centered around family values and moral standards, the prevention messages aimed at men emphasized the risks of extramarital sex. Among women, protective recommendations focused on a commitment to housework and to the husband's sexual satisfaction. Differences were observed between the social profiles of members of each group and between doctrinal messages. With most of their members coming from lower, rural classes, curative denominations display a more homogenous profile and lesser doctrinal flexibility. Mainline denominations, however, display greater social diversity, openness, and political connections, which means their members enjoy greater exposure to other messages and are more flexible about sexual morality. In other words, despite similarities between the messages of both religious types, the meaning assigned to each message depends upon members' educational level and social environment.

Likewise, research into the new meanings attributed to control over sexuality in the more well-to-do urban regions of Mozambique suggests that sexual mores may be growing more flexible. Some authors have observed that young, urban, educated middle-class females are more likely to challenge traditionally defined gender roles, putting them in a more advantageous position in sexual negotiations and leaving them less vulnerable 6,7. Karlyn 8 analyzes one sexual practice among young people in the capital of Mozambique, known as saca cena, where casual sexual contact does not follow traditional gender rules. During these practices, young females play an active role in sexual conquest and negotiation, indicating increased assimilation of prevention messages.

According to research, signs of new perceptions and new meanings within specific regions and groups are still rather insignificant. Studies focusing on national surveys show that for males and females aged 15 to 24 , their perception of the risk of acquiring HIV is unrealistic. Gender asymmetries are visible in the fact that men receive more education. Women tend to marry earlier and have relations only with their husbands, while men marry later and have a greater number of partners 9,10. Other studies have shown that involvement in a stable, monogamist relationship presents a major barrier to the use of condoms by young people, as the participants tend to place trust in their partner based on their established ties. Prevention campaigns reinforce this notion when they center on sexual abstinence, being 
faithful, and - only with occasional partners - using condoms 11.

The literature on Angola is similar in its analyses of the relations between social markers like gender, region, class, and educational level in defining prevention behavior. Research indicates that more consistent use of condoms (whether with a regular or casual partner) is related to: residing in an urban area, educational level, and not associating use of a condom with a lack of trust. Findings suggest that intervention should place priority on less educated, non-urban, and/ or unemployed youth 12. A unique aspect of the Angolan case is that the country's civil war helped lower the prevalence of HIV. But the end of the conflict and the return of soldiers increased vulnerability to disease, especially among women, because men contracted the disease in neighboring countries with high infection rates 13,14.

The relations between gender hierarchies, socio-economic conditions, and vulnerability to STD/AIDS were also the object of a study on the sociability network of marginalized young people in the urban region of Cape Verde 15. This research looked at the social value of marriage for women, which is reserved for those who fit the standards of purity (virginity) and control of sexuality. Those who do not conform to this model or who are from families that cannot guarantee bride wealth payment - still a common custom in Africa - tend to fall into prostitution or male exploitation. Other research shows how male polygamy and the custom of giving daughters away in marriage can contribute to the spread of HIV/ AIDS in various African countries 16

Studies on Guinea-Bissau, especially its rural regions, also note greater female vulnerability. In this case, it was observed that STD/AIDS exposure is related to longer conjugal life and to age (35), especially for HIV-2, which is prevalent in this country and rarer elsewhere around the world 17,18. Infection patterns appear to have been affected by the 1998-99 civil war, which introduced a significant amount of HIV-1 to the country. The consequences of this change are still under analysis 19 .

Sexual violence towards both regular and unknown partners, of different ages, appears in the literature as another serious problem in a number of African nations 20. Studies argue that the role that violence plays in the predominance of female STD/AIDS cases in sub-Sahara Africa may be underestimated in countries at war 21. Another factor that contributes to sexual violence is the belief that having sex with a young female virgin will cure AIDS 22. Female vulnerability in sub-Saharan Africa has also produced alarming cases of vertical transmission 23 .
Contrary to international academic production, in sub-Saharan Africa there is little research on HIV transmission through homosexual practices, and the issue is invisible in prevention policies. It has been stated that the role of same-sex relations in spreading HIV in this area of the world has been underestimated 24,25. The argument is that both homosexual and heterosexual anal sex is more common than admitted and may play a greater role in the AIDS epidemic on the African continent than recognized 26. Additional authors have addressed the topic of homosexuality in other national African contexts, focusing on representations and stigmatization vis-à-vis AIDS 27,28,29.

As to the relation of color or race to STD/ AIDS vulnerability, studies suggest that race relations in sub-Saharan African countries, where blacks are the majority, do not display the same bi-racial antagonism as in South Africa. The elites of these countries include both blacks as well as a white minority, which usually holds strategic posts in politics and the economy 30 . This means that the implications of the color/race dimension on public health in these contexts should be understood in the context of cultural factors, ethnic antagonism, and contrasts between rural, peri-urban, and urban groups. This differs from the consequences of the white versus black polarization as far as vulnerability to HIV/AIDS in the US context 31 .

\section{Shortcomings in prevention messages and the specificities of African countries}

According to the literature, prevention campaigns and messages in sub-Saharan Africa, which are often devised by international groups, focus primarily on the idea of sexual abstinence, as part of the ABC policy (abstinence, being faithful, and condom use), as opposed to the CNN approach (condoms, needles, and negotiation). The ABC proposal has been harshly criticized as an attempt to impose a kind of behavioral morality with ties to religious ideologies, since it encourages the use of condoms only among so-called highrisk groups - precisely those groups which are morally condemned, i.e., homosexuals, prostitutes, and injecting drug users. It has been argued that this guideline has contributed to condom rejection in contexts where religious influence and/ or macho traditions are strong 32,33 . The CNN approach, on the other hand, encourages condom use in any situation and/or sexual relation and also seeks to reduce danger for drug users. This method has been seen to achieve positive results in Uganda, Thailand, and Brazil and has been de- 
fended by Joint United Nations Programme on HIV/AIDS (UNAIDS), World Heath Organization (WHO) and United Nations Population Fund (UNFPA) ${ }^{34}$. Studies have concluded that prevention messages should demystify condom use and encourage frank and open discussions of sexuality in public forums and the media, without any tone of censure 35,36 .

One problem detected with prevention messages is a lack of awareness and understanding about local cultural dynamics and representations. Healthcare policies tend to be based on models imported from realities that differ from the local context and make no sense in the cultural logic of local social groups, thereby hampering communication ${ }^{3}$. In this regard, traditional medicines are broadly used in African nations and sometimes in association with Western medicine in health care ${ }^{37}$. Some research emphasizes that traditional healers' promises to cure STD/ AIDS keep people from relying on available antiretroviral treatment 38 . Other research argues that medical and surgical procedures and tribal or healer customs 39,40 - like female genital mutilation - increase the risks of HIV transmission through the use of non-sterilized needles and cutting instruments 41,42 .

Given that $80 \%$ of the African population relies on traditional medicines for its health care, the literature argues that prevention policies must work to reconcile so-called native discourses with those of Western medicine ${ }^{43}$. Some analyses state that the integrated use of traditional and Western practices in African societies depends upon each disease's identity and cause, so it is important to understand how these logics operate. For instance, depending upon how symptoms are interpreted, a disease may be defined as "by chance" (lacking a social or moral cause), "modern" (introduced by foreigners), or "African" (found solely among Africans). The causes of a disease are understood in terms of how it is acquired (e.g., contact with special fluids or pollutants) and why (e.g., breaking social or moral rules) 44 . The causation of STDs is usually associated with witchcraft, because reproduction is so highly valued in traditional African thought. It has been suggested that biomedical explanations can be incorporated into traditional beliefs. There are limitations, however, especially because of mistrust of the safe-sex message, which conflicts with the value of fertility and the logic of witchcraft.

In the effort to identify potential linkages between modern prevention messages and traditional local cosmologies, the point has been made that the use of suitable prophylactic methods should be encouraged during rituals like male circumcision 45 , which could decrease HIV transmission both during and after the procedure 46 . Another study points out that it is not just socio-economic and educational status that influences greater acceptance or linkage of messages but also the availability of resources for the population. It has been shown that accessible Western contraceptive methods are preferred by women from urban and semi-rural areas given their restrictions about traditional methods, e.g., the cost of traditional healer services 47 .

An additional characteristic of the African continent are the countless civil wars that produce migratory movements between neighboring countries. This contributes to the spread of the HIV/AIDS epidemic, because of refugee infection rates, sexual violence, the absence of a protection network or healthcare facilities, psychological stress, and poverty. The end of the wars does not attenuate this phenomenon, since the return to one's native land helps propagate diseases 40,48,49. Angola illustrates this. Understanding the dynamics of the epidemic in times of war and post-war may offer the key to discovering how to effectively contain the epidemic not only in Angola but in other countries as well 13.

\section{Conclusion}

This review of the literature on the challenges of STD/AIDS prevention in Portuguese-speaking African countries identified a larger number of studies on Mozambique. Although cultural and socio-economic similarities were noted between countries, we must better understand each of the local contexts of this region of Africa.

While this survey was not exhaustive, and a bibliographic review is necessarily limited in scope within the space of a forum, the research described does provide a panorama of the main conditions defining different social groups' vulnerability to STD/AIDS in African contexts. The studies show how healthcare practices, gender roles, and the interpretation of prevention messages are mediated by local cultural traditions and by socio-economic and political contexts. This information underscores the importance of further advances in the realm of basic citizenship rights and equal opportunities among social sectors and between genders. Given the observed variations in sexual, racial, and gender identities and cultural traditions in the spheres of health and religion, these efforts should be guided by critical assessments of prevention programs, which have been built on the assumption that different social groups display homogenous views and practices. It is therefore necessary for 
biomedicine to expand its pragmatic focus in AIDS prevention policies in African societies by coming to understand local cultural values and by linking native messages and practices with those of modern Western medicine.

\section{Resumo}

O artigo analisa a produção acadêmica, no campo das ciências sociais e da saúde, sobre os problemas e desafios das ações de prevenção das DST/AIDS nos países africanos de língua oficial portuguesa. A partir do levantamento bibliográfico nas bases SciELO, PubMed e Sociological Abstracts, entre 1997 a 2007, o conteúdo dos trabalhos selecionados foi organizado em dois eixos. O primeiro centra-se na descrição dos estudos sobre a relevância dos fatores culturais e sócio-econômicos locais, relacionados às dinâmicas de gênero, à sexualidade, cor/raça, religião e cuidados em saúde, para o entendimento da vulnerabilidade às DST/AIDS dos diversos grupos sociais. O segundo eixo aborda as avaliações críticas acerca dos equívocos das mensagens educativas sobre DST/AIDS, promovidas pelos governos e agências internacionais, bem como as implicações da presença dos sistemas de medicinas tradicionais e da ocorrência de guerras civis no período pós-colonial para a dinâmica das DST/AIDS nos contextos nacionais africanos pesquisados.

Síndrome de Imunodeficiência Adquirida; Doenças Sexualmente Transmissíveis; Prevenção; Gênero; África
This analysis of international academic production detected regional specificities alongside dimensions shared by countries around the world, indicating that initiatives to fight the epidemic should be guided by a recognition of both the local and the global.

\section{Acknowledgments}

My thanks to Felippe Mendonça for his work in surveying and systematizing data. 


\section{References}

1. Owen M. The bottom line: Mozambique. Plan Parent Chall 1997; 1:45-7.

2. Agadjanian V. Gender, religious involvement, and HIV/AIDS prevention in Mozambique. Soc Sci Med 2005; 61:1529-39.

3. Pfeiffer J. Condom social marketing, Pentecostalism, and structural adjustment in Mozambique: a clash of AIDS prevention messages. Med Anthropol Q 2004; 18:77-103.

4. Velayati AA, Bakayev V, Bahadori M, Tabatabaei SJ, Alaei A, Farahbood A, et al. Religious and cultural traits in HIV/AIDS epidemics in sub-Saharan Africa. Arch Iran Med 2007; 10:486-97.

5. Agadjanian V, Sen S. Promises and challenges of faith-based AIDS care and support in Mozambique. Am J Public Health 2007; 97:362-6.

6. Chapman RR. A nova vida: the commoditization of reproduction in Central Mozambique. Med Anthropol 2004, 23:229-61.

7. Pfeiffer J. Cash income, intrahousehold cooperative conflict, and child health in central Mozambique. Med Anthropol 2003; 22:87-130.

8. Karlyn AS. Intimacy revealed: sexual experimentation and the construction of risk among young people in Mozambique. Cult Health Sex 2005; 7:279-92.

9. Prata N, Morris L, Mazive E, Vahidnia F, Stehr M. Relationship between HIV risk perception and condom use: evidence from a population-based survey in Mozambique. Int Fam Plann Perspect 2006; 32:192-200.

10. Font A, Puigpinãs R, Chichango IE, Cabrero N, Borrell C. AIDS-related knowledge and behaviors in Mozambique. Rev Epidemiol Sante Publique 2006; 54:341-54.

11. Manuel S. Obstacles to condom use among secondary school students in Maputo city, Mozambique. Cult Health Sex 2005; 7:293-302.

12. Prata N, Vahidnia F, Fraser A. Gender and relationship differences in condom use among 15-24year-olds in Angola. Int Fam Plann Perspect 2005; 31:192-9.

13. Flechner D. A human rights approach to protecting people living with HIV/AIDS in Angola. Int Soc Sci J 2005; 57:627-37.

14. Strand RT, Fernandes-Dias L, Bergström S, Andersson S. Unexpected low prevalence of HIV among fertile women in Luanda, Angola. Does war prevent the spread of HIV? Int J STD AIDS 2007; 18:467-71.

15. Anjos JC. Sexualidade juvenil de classes populares em Cabo Verde: os caminhos para a prostituição de jovens urbanas pobres. Revista Estudos Feministas 2005; 13:163-77.

16. Dada-Adegbola HO. Socio-cultural factors affecting the spread of HIV/AIDS in Africa: a case study. Afr J Med Sci 2004; 33:179-82.

17. Holmgren B, Silva Z, Vastrup P, Larsen O, Andersson S, Ravn H, et al. Mortality associated with HIV1, HIV-2, and HTLV-I single and dual infections in a middle-aged and older population in GuineaBissau. Retrovirology 2007; 4:85.
18. Mansson F, Alves A, Silva ZJ, Dias F, Andersson S, Biberfeld G, et al. Trends of HIV-1 and HIV-2 prevalence among pregnant women in Guinea-Bissau, West Africa: possible effect of the civil war 19981999. Sex Transm Infect 2007; 83:463-7.

19. Poulsen AG, Aaby P, Jensen H, Dias F. Risk factors for HIV-2 seropositivity among older people in Guinea-Bissau. A search for the early history of HIV-2 infection. Scand J Infect Dis 2000; 32: 169-75.

20. Abrahams N, Jewkes R, Hoffmann M, Laubsher R. Sexual violence against intimate partners in Cape Town: prevalence and risk factors reported by men. Bull World Health Organ 2004; 82:330-7.

21. Klot J, DeLargy P. Sexual violence and HIV/AIDS transmission. Forced Migration Review 2007; 27:23-4.

22. Meel BL. The myth of child rape as a cure for HIV/ AIDS in Transkei: a case report. Med Sci Law 2003; 43:85-8.

23. Medley A, Garcia-Moreno C, McGill S, Maman S. Rates, barriers and outcomes of HIV serostatus disclosure among women in developing countries: implications for prevention of mother-to-child transmission programmes. Bull World Health Organ 2004; 82:299-307.

24. Lorway R. Dispelling "heterosexual African AIDS" in Namibia: same-sex sexuality in the township of Katutura. Cult Health Sex 2006; 8:435-49.

25. Wakabi W. Homophobia is fuelling the AIDS epidemic in Africa. Can Med Assoc J 2007; 177:1017.

26. Brody S, Potterat JJ. Assessing the role of anal intercourse in the epidemiology of AIDS in Africa. Int J STD AIDS 2003; 14:431-6.

27. Ehlers VJ, Zuyderduin A, Oosthuizen MJ. The wellbeing of gays, lesbians and bisexuals in Botswana. J Adv Nurs 2001; 35:848-56.

28. Kiama W. Where are Kenya's homosexuals? AIDS Anal Afr 1999; 9:9-10.

29. Maartens G, Wood R, O'Keefe E, Byrne C. Independent epidemics of heterosexual and homosexual HIV infection in South Africa - survival differences. QJM 1997; 90:449-54.

30. Passador LH, Thomaz OR. Raça, sexualidade e doença em Moçambique. Revista Estudos Feministas 2006; 14:263-86.

31. Hucks TC. Racial and sexual orientation identity and social support as predictors of sexual risk-taking behavior among African-American men who have sex with men. Dissertation Abstracts International, Section A: The Humanities and Social Sciences 2005; 65:2780-A.

32. Sinding SW. Does "CNN" (condoms, needles, negotiation) work better than "ABC" (abstinence, being faithful and condom use) in attacking the AIDS epidemic? Int Fam Plann Perspect 2005; 31:38-40.

33. Ntshebe O, Pitso JM, Segobye AK. The use of culturally themed HIV messages and their implications for future behaviour change communication campaigns: the case of Botswana. SAHARA J 2006; 3:466-76

34. Hearst N, Chen S. Condom promotion for AIDS prevention in the developing world: is it working? Stud Fam Plann 2004; 35:39-47. 
35. Underwood C, Hachonda H, Serlemitsos E, Bharath-Kumar U. Reducing the risk of HIV transmission among adolescents in Zambia: psychosocial and behavioral correlates of viewing a risk-reduction media campaign. J Adolesc Health 2006; 38:55.

36. Murphy EM, Greene ME, Mihailovic A, OlupotOlupot P. Was the "ABC" approach (abstinence, being faithful, using condoms) responsible for Uganda's decline in HIV? PLoS Med 2006; 3:e379.

37. Kotanyi S. Relevance of indigenous concepts of disease and contamination in the socio-cultural context for an effective HIV/AIDS prevention in Mozambique. Curare 2005; 28:247-64.

38. Kamatenesi-Mugisha M, Oryem-Origa H. Traditional herbal remedies used in the management of sexual impotence and erectile dysfunction in western Uganda. Afr Health Sci 2005; 5:40-9.

39. Salami KK, Titiloye MA, Brieger WR, Otusanya AS. Observations of barbers' activities in Oyo State Nigeria: implications for HIV/AIDS transmission. Int Q Community Health Educ 2005/2006; 24:319-30.

40. Gisselquist D. Impact of long-term civil disorders and wars on the trajectory of HIV epidemics in sub-Saharan Africa. SAHARA J 2004; 1:114-27.

41. Adams J, Trinitapoli J, Poulin M. Regarding "male and female circumcision associated with prevalent HIV infection in virgins and adolescents in Kenya, Lesotho, and Tanzania". Ann Epidemiol 2007; 17:923-5.
42. Yount KM, Abraham BK. Female genital cutting and HIV/AIDS among Kenyan women. Stud Fam Plann 2007; 38:73-88.

43. Homsy J, King R, Tenywa J, Kyeyune P, Opio A, Balaba D. Defining minimum standards of practice for incorporating African traditional medicine into HIV/AIDS prevention, care, and support: a regional initiative in eastern and southern Africa. J Altern Complement Med 2004; 10:905-10.

44. Liddell C, Barrett L, Bydawell M. Indigenous representations of illness and AIDS in Sub-Saharan Africa. Soc Sci Med 2005; 60:691-700.

45. Niang CI, Boiro H. "You can also cut my finger!": social construction of male circumcision in West Africa, a case study of Senegal and Guinea-Bissau. Reprod Health Matters 2007; 15:22-32.

46. Eyer-Silva WA. A circuncisão masculina e a transmissão heterossexual do HIV. Rev Saúde Pública 2003; 37:678-86.

47. Agadjanian V. Women's choice between indigenous and Western contraception in urban Mozambique. Women Health 1998; 28:1-17.

48. Mills EJ, Singh S, Nelson BD, Nachega JB. The impact of conflict on HIV/AIDS in sub-Saharan Africa. Int J STD AIDS 2006; 17:713-7.

49. Foreit KF, Barreto AT, Noya PA, Nhatave I. Population movements and the spread of HIV/AIDS in Mozambique. J Health Hum Serv Adm 2001; 24:279-94.

Submitted on 25/Aug/2008

Approved on 29/Sep/2008 